\title{
Os modos de enunciação nos Manuais de Ensino para professores de História
}

\author{
André Luiz Paulilo
}

\section{Introdução}

Entre as muitas formas que assume a atividade discursiva, aquela que motivou esta pesquisa ${ }^{1}$ é, antes de tudo, um produto didático-escolar, destinado a orientar e organizar uma prática de ensino. Trata-se da análise de um gênero textual que interpela o docente-leitor, pressupondo-o e instaurando-o explicitamente no discurso. $\mathrm{O}$ estudo dos manuais do professor dos livros didáticos de História recomendados pelo Programa Nacional do Livro Didático de 2008 (PNLD-2008) permite, sobretudo, lidar com as representações sociais que esse artifício de comunicação mobiliza e repercute. Os indícios linguísticos que materializam o leitor, que os autores desses impressos têm em mente, valem como rastros dos processos através dos quais esses autores expressam um pensamento sobre a docência. Do mesmo modo, as pistas linguísticas responsáveis por introduzir no texto a posição do autor contribuem para a percepção dos mecanismos persuasivos que se utiliza no texto. Para Prost, essas são duas operações necessárias ao estudo de uma enunciação. Segundo ele entende, uma maneira de dissolver a evidência das significações imediatas é atentar para "a relação entre o texto e aquele que o produziu, entre o enunciado realizado e o enunciador".

As liçōes dadas por Benveniste, Searle, e Foucault há tempos mostraram os discursos como atos ou práticas que fazem com que apareça "um domínio de estruturas e de unidades possíveis com conteúdos concretos, no tempo e no espaço". ${ }^{3}$ Esse é também o âmbito das contribuições de Jakobson, Greimas, Kerbrat-Orecchioni e Fiorin para o estudo da enunciação pelo menos de dois modos, por uma teoria narrativa ou, senão, por meio da semiótica. ${ }^{4}$ As discussões desses autores desenvolveram algumas das mais esclarecedoras abordagens sobre a atividade discursiva, contribuindo para entender as astúcias da enunciação e os seus usos a partir da análise do discurso. Entre as exigências metodológicas de análise da palavra organizada em discurso, a linguística propõe tratar a enunciação como sistema, tomando-a a partir de esquemas gerais que permanecem invariantes sob a diversidade infinita dos atos particulares de fala. Desde que se desenvolveu uma linguística do discurso, não mais se opõe, conforme adverte Catherine Kerbrat-Orecchioni, "a enunciação ao enunciado como o ato ao seu produto". 5 Sob esse aspecto, o mais das vezes há pesquisas que buscam identificar e descrever os traços do ato no produto.

O estudo da enunciação permite localizar alguns sinais da demanda e compreender os apelos de mudança sobre o trabalho do professor de História. E esses sinais e apelos são numerosos hoje na sociedade. A opinião pública se indigna periodicamente com a cultura histórica dos estudantes do país. Vez por outra a imprensa publica sondagens sobre a má formação, real ou suposta, dos docentes. Não está distante disso a polêmica que em 2007 o livro História Crítica de Mário Schmidt suscitou na imprensa, mesmo sem estar recomendado pelo PNLD de História do ano seguinte. O ensino da História é, portanto, parte do debate público a respeito da qualidade da educação e, nessa condição, um objeto de discussões ativas. Considerando-se as posições de Bakhtin acerca das possibilidades de análise da comunicação verbal, os manuais do professor dos livros didáticos também são uma forma de participar dessas discussões. Sua abordagem chama a atenção para o papel dos livros na interação verbal. Segundo Bakhtin também o livro constitui um elemento da comunicação verbal. ${ }^{6}$

Para Bakhtin, a ideia de enunciação também serviu para designar o discurso escrito. Na obra desse autor, o livro e os textos são considerados atos de fala impressos e, então, sujeitos aos mesmos princípios da interação verbal presentes no diálogo. Foi Bakhtin quem tratou pela primeira vez as astúcias da 
enunciação a partir do estudo dos gêneros textuais e do estilo. Por meio do emprego de conceitos como dialogismo, polifonia e heteroglossia, mostrou que, sob as palavras de alguém, ressoa a voz de outrem. ${ }^{7}$ A obra de Bakhtin permite, principalmente, entender as diferentes instâncias enunciativas instauradas no texto. Por meio dela se vêm discutindo, entre outras questōes, as diferentes vozes que podem ser ouvidas em um texto, ${ }^{8}$ as astúcias e as estratégias da enunciação ${ }^{9}$ e mesmo as orientações sociais que se manifestam nos textos. ${ }^{10}$ Em muitos sentidos, as perspectivas abertas por Bakhtin para os estudos da linguagem sugerem que também os textos são um produto da interação social, não só determinados pela situação imediata ou pelo contexto que constitui o conjunto das condiçóes de vida de uma determinada comunidade linguística, como também feitos para serem apreendidos de maneira ativa, para serem estudados e comentados. ${ }^{11}$

Essa ideia de texto me pareceu muito apropriada para o estudo do "Manual do Professor" nos livros didáticos recomendados pelo PNLD-2008. Com efeito, trata-se de um tipo de publicação específico, escrito para o professor, feito mais para ser utilizado no dia-a-dia, do que para ser lido, e cuja distribuição gratuita garante a sua circulação nas escolas. Nesse sentido, pode ser entendido como um objeto editorial que, como diria Bakhtin, "responde a alguma coisa, refuta, confirma, antecipa as respostas e objeções potenciais e procura apoio". ${ }^{12}$ Já para a maior parte das análises a respeito da produção do livro didático no Brasil parece claro que a oferta pedagógica trazida nesse material procura se inserir diretamente no contexto não verbalizado da prática docente e nele se ampliar pela ação, pelo gesto ou pela atitude do leitor. Sobretudo a perspectiva elaborada por Bakhtin para pensar a linguagem dos textos permite abordar os termos em que se dá a apreensão da situação de enunciação pelos recursos linguísticos do discurso. De modo que, para discutir o ensino de História proposto nos manuais do professor, recorri às concepções de obra, criação verbal, compreensão responsiva e do problema da comunicação social enunciadas por Bakhtin.

O propósito deste estudo, portanto, é perscrutar as formas e os tipos de interação verbal a que se prestam os manuais do professor dos livros didáticos de História recomendados pelo PNLD-2008. Por essa razão, debrucei-me sobre o gênero dos seus textos, a intenção discursiva dos seus autores e a posição semântica que os docentes ocupam neles. A aposta da análise que se segue está em compreender as formas como os manuais do professor se dirigem ao docente-leitor, à sua experiência e consciência.

\section{O gênero didático}

No "Manual do Professor" utiliza-se um tipo relativamente estável de enunciados. Tanto a construção composicional e o estilo de linguagem desses textos são específicos quanto às suas condições de enunciação e finalidades próprias. A despeito das diferenças de acento e enfoque, há protocolos de leitura que são observados por todas as coleções recomendadas pelo PNLD-2008. Invariavelmente, nos manuais do professor de História são discutidos, na partida, os pressupostos teóricos da coleção, sua fundamentação metodológica e linha historiográfica. Após isso, tratam-se dos procedimentos de trabalho propostos na coleção e da organização didática dos conteúdos, dos temas ou da ordem dos capítulos. Por um lado, expõe-se a metodologia de ensino desenvolvida pela coleção, os seus princípios pedagógicos, seu modo de trabalhar e de fazer trabalhar com as fontes e as estratégias explicativa e de investigação adotadas. De outro, ficam explícitas, por meio de considerações gerais sobre os propósitos da edição do livro didático, as questôes de estruturação da coleção como objetivos, sequência e encadeamento das unidades e iconografia. Depois disso, uma proposta de avaliação é apresentada e justificada. Seguem-se seções com sugestôes de material didático suplementar, geralmente filmes, músicas e sítios eletrônicos, e de bibliografia complementar de ensino para o professor.

O estudo que Bakhtin produziu sobre os gêneros do discurso mostra-se útil à compreensão das relaçóes entre os enunciados e a especificidade do campo de atividade no qual foram produzidos. De acor- 
do com as conclusōes, a composição das fórmulas correntes de expressão, ou dos seus protocolos de leitura, se formam nas condições da comunicação discursiva imediata. Assim, para Bakhtin, na abordagem dos vestígios que a vida deixa na linguagem o enunciado é um núcleo problemático de importância. Entre os locais da enunciação, onde os pesquisadores haurem os fatos linguísticos de que necessitam, os manuais do professor são aqueles nos quais melhor podem operar com as evidências das escolhas técnicas e procedimentais dirigidas ao magistério já em serviço. Em notáveis estudos históricos sobre os manuais de ensino, Choppin e Anne-Marie Chartier insistem que os textos regulamentares oficiais e o cotidiano da profissão docente impõem condições à enunciação dos autores de obras didáticas. ${ }^{13}$ Não só o poder político define muito do que se deve tratar, como o que se sabe sobre o trabalho do dia-a-dia na sala de aula produz demandas específicas. Portanto, a composição típica dos textos dos manuais efetua-se na interação verbal entre quem governa, aquele que a produz, os seus usuários e os críticos. Nesse aspecto, a historiografia adverte ainda que um formalismo demasiado e uma abstração exagerada da investigação justamente deformam a historicidade das relaçôes da língua com a atividade humana que a enunciou.

Os manuais do professor que acompanham os livros didáticos recomendados pelo PNLD possuem a estabilidade e o padrão típico de construção dos enunciados de um gênero discursivo. Trata-se de uma forma normalizada, mas segura, da vontade discursiva de um autor se manifestar. Ainda que, conforme explica Bakhtin, bem mais flexíveis, plásticas e livres que as formas da língua, as formas de gênero também moldam o discurso. Assim, a despeito de toda individualidade e do caráter criativo que distinguem cada um desses manuais entre si, há formas indispensáveis e obrigatórias para a compreensão do que se enuncia em um "Manual do Professor". A análise delas pode servir de guia para o estudo do tipo de composição utilizada, suas condições de elaboração e aplicação. A maneira como Bakhtin estudou os gêneros do discurso sugere que a conclusividade de significado, a expressividade e o endereçamento são os principais elementos constitutivos das formas de enunciação. Seguindo esse modelo, tais elementos são determinados pelo campo da atividade humana e da vida às quais o enunciado se refere. Para Bakhtin, não só a escolha do gênero de discurso é determinada pelas tarefas do sujeito e em consideração às atitudes em prol das quais o enunciado é criado, como também em função da força e da influência do destinatário no enunciado. ${ }^{14}$

A tarefa precípua do "Manual do Professor" é orientar o docente na utilização do livro didático. Esse sentido da obra determina as suas peculiaridades estilístico-composicionais. Um manual didático mais se parece com um guia de trabalho para ser utilizado no dia-a-dia e ele impóe conteúdos, uma progressão, exercícios e modalidades de avaliação. A divisão do texto em numerosas seçôes, a sua eventual organização por tópicos, a presença de excertos de outros textos, as sucessivas indicações bibliográficas sistematizam um repertório considerável de instruções e referências para o trabalho docente. A opção por textos que informam sobre o conteúdo ou por explicações acerca da realização das atividades, o uso, ou não, de orientações cartográficas, a frequente remissão ao livro do aluno e demais recursos para orientar o trabalho docente em sala de aula também compóem o conteúdo semântico-objetal ${ }^{15}$ dos manuais dos professores. O rico arsenal de recursos linguísticos de que o "Manual do Professor" se vale para exprimir o objeto do seu discurso inclui procedimentos didáticos específicos. Em muitos sentidos, a obra didática reproduz e combina fórmulas já experimentadas de transmissão dos conteúdos e dos seus métodos e categorias de estruturação. Portanto, entre as suas particularidades estilístico-composicionais podem ser percebidos os imperativos didáticos da cultura escolar a qual se destina.

No "Manual do Professor" se efetiva um copioso registro do trabalho didático que supõe o exercício da docência. De modo que, nesse tipo de impresso também se vê o modo propriamente escolar de escansão do tempo, a repartição das atividades no interior do ano, a duração dada às sequências de curso, o ritmo de exercícios e controles diversos. Entre os seus traços estilístico-composicionais, predominam valores, preocupações e recursos que não escaparam aos estudos acerca dos saberes e das discipli- 
nas escolares. Sobretudo porque os manuais dos professores respeitam boa parte da economia interna que distingue a escola de outras entidades culturais, sua morfologia também se constitui a partir das rotinas escolares de ensino mais comuns. Em todos os manuais do professor dos livros didáticos de História recomendados pelo PNLD-2008 os valores de apresentação e de clarificação predominam. Não só há nesses textos uma marcante preocupação com a progressividade e a sua divisão formal em partes e subpartes, como com a abundância de redundâncias na informação, o recurso aos comentários explicativos e às técnicas de condensação. Igualmente, as esquematizações, a exemplificação e o lugar concedido às questôes e aos exercícios cumprem uma função de controle ou de reforço pelo qual se reconhece o gênero didático de comunicação. Como sublinharam Chervel e Forquin, quando analisaram as condições de realização prática cotidiana do ofício de escolar, os savoir-faires internos à sala de aula, as competências operatórias de curto alcance e de função adaptativa, os rituais, as rotinas e as receitas constituem o campo da atividade humana ao redor do qual se vulgarizam os procedimentos de ensino e se fixam as suas representaçóes. ${ }^{16}$

A relação que os autores dos manuais do professor estabelecem com o seu conteúdo semântico-objetal é outro elemento desse tipo de enunciado. Esse não-próprio das palavras que, no entanto, lhes tornam uma espécie de representante da plenitude do enunciado como posição valorativa, é para Bakhtin a expressão da autoridade de um autor. ${ }^{17} \mathrm{Na}$ ordem de preocupações de Bakhtin, trata-se de pensar o processo de criação do enunciado a partir do contato que mantém com a realidade concreta. Assim, a especificação do gênero didático aludido acima determina um primeiro âmbito de composição temática e de estilo. Os valores pedagógicos e políticos, as preferências culturais e estéticas, a experiência com a aprendizagem escolar do autor e os rastros do processo que organizam no discurso também determinam opções e prioridades. As opções pela história temática ou pelo encadeamento cronológico dos conteúdos, pela integração dos conteúdos de história geral e do Brasil, ou não, e entre uma abordagem acentuadamente historiográfica, ou marcada pelas metodologias da aprendizagem nas coleções didáticas de História recomendadas em 2008 refletem algo sobre as escolhas que hoje é possível identificar no ensino de História.

Mikhail Bakhtin observa que a relação subjetiva emocionalmente valorativa do autor-falante com o conteúdo do objeto e do sentido do seu enunciado é um elemento expressivo determinante da composição e do estilo do discurso e adverte sobre a existência de "alguns contatos típicos dos significados das palavras com a realidade concreta". ${ }^{18}$ No caso de alguns dos manuais do professor que acompanham os livros didáticos de História, o tom expressivo de palavras como "olhar" ou "mudança” não são típicos dessas palavras. Determinadas pelo contexto, essas palavras se prestam a uma reacentuação que lhes modifica o sentido. Por meio do recurso aos desenvolvimentos perifrásticos e de sinestesia se realiza a transferência de percepções da esfera de um sentido para a de outro, do que resulta uma fusão de impressões com poder sugestivo, como em: "O aluno deve aprender a olhar a realidade com 'olhos históricos", ou "O Big-Bang poderia ser comparado, por exemplo, à descoberta do amor, ou a uma grande mudança na vida que, depois de um período 'estrondoso', de grande confusão, dá origem a 'novos mundos". Esse tipo de expressividade pode ser vista como um efeito estilístico da necessidade funcional da didatização atribuída por Forquin aos saberes escolares. ${ }^{19}$

A predominância dos valores de apresentação e de clarificação e os recursos linguísticos de sua expressividade determinam, ao lado do elemento semântico-objetal, o gênero dos manuais para professores de História. Ainda segundo a proposta de análise de Bakhtin, não basta estudar as formas estáveis e normativas típicas de um enunciado para se compreender a realidade viva e as funções sociais de um determinado gênero discursivo. ${ }^{20}$ Para Bakhtin, o enunciado ocupa uma posição definida em uma dada esfera da comunicação, em uma dada questão, em um dado assunto, sendo impossível alguém definir sua posição sem correlacioná-la com outras posiçōes. ${ }^{21} \mathrm{O}$ corolário dessa perspectiva é o de que "cada enunciado é pleno de variadas atitudes responsivas a outros enunciados de dada esfera da comunica- 
ção discursiva". ${ }^{22}$ No que diz respeito aos manuais do professor que acompanham os livros didáticos de História recomendados pelo PNLD-2008, verifica-se que, em certa medida, não deixam de ser também uma resposta àquilo que já foi escrito sobre o ensino de História. Entre as condições de produção desse tipo de texto, a reassimilação dos enunciados de outros sobre o ensino de História determina o destaque dado a determinados elementos, as repetições e a escolha de certos tipos de expressóes. Assim, as sistemáticas referências aos documentos oficiais, à história social inglesa e à nova história cultural, o recurso à citação dos recentes resultados de pesquisas acerca do ensino de História e do livro didático no Brasil e também o uso de noções típicas dessas discussões deixam evidente a tonalidade dialógica ${ }^{23}$ dos enunciados de que se compóem os manuais do professor recomendados para a área de História.

Outro traço constitutivo do enunciado é então o seu endereçamento, o seu direcionamento a alguém. Do mesmo modo que se compreende que um discurso está voltado não só para o seu objeto, mas igualmente para os discursos do outro sobre ele, que se constrói levando em conta as atitudes responsivas, também está posto que esse discurso tem um destinatário. Para Bakhtin, tanto a composição quanto o estilo do enunciado dependem da força e da influência do destinatário no discurso, pois, como o falante, o escritor percebe e representa para si os seus destinatários. ${ }^{24}$ Nesse sentido, é a concepção típica de docente que determina o "Manual do Professor" como gênero. Ainda segundo a perspectiva de Bakhtin, o autor do enunciado presume uma resposta dos destinatários, construindo o texto ao encontro dessa resposta na espera de uma ativa compreensão responsiva $a^{25}$ Trata-se de uma percepção do papel ativo que o destinatário do enunciado cumpre na construção dos discursos, uma vez que ao se escrever para um público determinado póe-se em conta a influência dele sobre a comunicação. Principalmente, quando se dá uma resposta pronta às objeções já previstas ou se apela para toda sorte de subterfúgios, ficam as pistas de uma tentativa de responder o que ainda está por vir com a leitura de um enunciado. Outro conjunto de operações leva em conta o fundo aperceptivel da percepção de um enunciado pelo destinatário: "até que ponto está a par da situação, dispõe de conhecimentos especiais de um dado campo cultural da comunicação, suas concepções e convicções, os seus preconceitos, as suas simpatias e antipatias" 26

A literatura didática endereçada aos professores, na forma de manual, resulta da escolha de procedimentos composicionais e meios linguísticos que refletem a posição social, o título e o peso do destinatário. Os manuais do professor contêm indícios que materializam o leitor que o autor tem em mente e, assim, dão o registro de uma forma específica de compreender o docente e o exercício da docência. $\mathrm{O}$ estudo histórico das mudanças desse tipo de registro sobre o trabalho docente tem se mostrado uma tarefa interessante e importante. ${ }^{27} \mathrm{~A}$ história do ensino de História mostra que, tanto há formas convencionais de apelo aos leitores-docentes ${ }^{28}$ quanto existe, paralelamente ao autor real, representaçôes de autores testa-de-ferro, editores, narradores de toda espécie. ${ }^{29}$ É prudente que um estudo da situação da produção atual não deixe de considerar que, cada época, tem como característica suas concepções específicas de destinatário do manual, a sensação especial e a compreensão do seu leitor. Mais uma vez, em uma época na qual é destacado o papel do leitor e seu horizonte de expectativas na construção do significado, as noções de atitude e compreensão responsivas são de relevância para o estudo das representações que se têm da docência em História. ${ }^{30}$

\section{Elaboração didática da História}

As discussōes sobre a utilização do livro didático nas aulas de História frequentemente tratam da intermediação do professor - que o escolhe, seleciona os capítulos ou partes que devem ser lidos e dá orientaçôes aos alunos ${ }^{31}$ - e ignoram o papel do professor para quem escreve obras didáticas. No entanto, Circe Bittencourt adverte que, desde seu processo inicial de confecção, os manuais didáticos pressupõem uma leitura que necessita da intermediação do professor. ${ }^{32}$ Nesse sentido, Araújo constatou que é comum o uso do livro didático na preparação das aulas e no planejamento e que "o grau de dependência 
dos professores em relação a esse material está associado à sua formação e às condições de trabalho". ${ }^{33}$ No "Manual do Professor", são justamente as demandas de uso do livro didático, no preparo das aulas e as questões de apropriação da obra didática pelo docente, que o autor pressupõe e procura responder. Conforme propõe Bakhtin, esse empenho do autor em tornar inteligível o seu enunciado indica que "ele não espera uma compreensão passiva, por assim dizer, que apenas duble o seu pensamento em voz alheia, mas uma resposta, uma concordância, uma participação, uma objeção, uma execução" ${ }^{34}$ Como tantos outros gêneros do discurso escrito, o "Manual do Professor" é concebido para essa compreensão ativamente responsiva de efeito retardado:

Todo enunciado - da réplica sucinta do diálogo cotidiano ao grande romance ou tratado científico - tem, por assim dizer, um princípio absoluto e um fim absoluto: antes do seu início, os enunciados de outros; depois do seu término, os enunciados responsivos de outros (ou ao menos uma compreensão ativamente responsiva silenciosa do outro ou, por último, uma ação responsiva baseada nessa compreensão). O falante termina o seu enunciado para passar a palavra ao outro ou dar lugar à sua compreensão ativamente responsiva. ${ }^{35}$

Na perspectiva de Bakhtin, a obra está disposta para a resposta do outro, para a sua ativa compreensão responsiva que, como a réplica do diálogo, pode assumir diferentes formas: "influência educativa sobre os leitores, sobre suas convicções, respostas críticas, influência sobre seguidores e continuadores". Ainda significativo para o entendimento da enunciação, Bakhtin insiste que a vontade discursiva do autor que produziu a obra "sempre leva em conta o fundo aperceptível da percepção do seu discurso pelo destinatário". ${ }^{36}$ Nesse modo de compreender as relaçôes entre os meios linguísticos do discurso e a expressividade e endereçamento dos seus enunciados, verifica-se que a comunicação discursiva impõe ao falante, como também ao autor, uma atitude responsiva direta. As pistas linguísticas que esse fenômeno introduz numa obra permitem perceber as escolhas dos procedimentos composicionais e, assim, parte das relações entre o texto e aquele que o produziu. O sistema de pronomes, os advérbios de circunstância, os conectivos, o tempo dos verbos e suas modalizaçôes trazem a marca daquele que produziu o texto, indicam os usos que se fez das categorias de pessoa, espaço e tempo na enunciação. ${ }^{37}$ Nesse sentido, são todos vestígios do direcionamento e das respostas às objeções já previstas, das tonalidades dialógicas, da maior ou menor influência do destinatário e da vontade discursiva que determinaram a escolha dos recursos linguísticos feita por um autor.

Nos manuais do professor, geralmente o autor não se envolve pessoalmente com seu discurso. À exceção de incisos nos quais ele então assume a responsabilidade das suas análises e posições, os enunciados são pouco modalizados e evitam confrontar o leitor. Para Bakhtin ${ }^{38}$ tal estilo, objetivo-neutro, produz uma seleção de meios linguísticos extremamente genérica e abstraída do seu aspecto expressivo. É o que também se verifica nos manuais do professor recomendados pelo PNLD-2008. Não só as considerações gerais sobre o formato e o uso do suplemento do professor se apoiam numa forma de autoridade científica específica, como as orientações sobre as atividades propostas têm, entre suas principais características, o uso do modo imperativo, as repetições e redundâncias e a impessoalidade. No conjunto desses textos, subsiste mais a preocupação de explicar que a de convencer e, portanto, sua "objetividade" não é senão o efeito de um discurso de instituição. ${ }^{39}$ Em 2008, quase a totalidade das obras didáticas de História recomendadas pela primeira vez no PNLD não rediscutem os paradigmas historiográficos ou representam uma nova proposta de ensino-aprendizagem e de didática da História. ${ }^{40}$ Apenas a coleção publicada por Andréa Paula, Carla Ferraresi e Conceição de Oliveira ${ }^{41}$ recebeu viva recomendação no Guia de Livros Didáticos PNLD-2008: História, tanto por incorporar importantes elementos da renovação historiográfica, quanto por propor estratégias pedagógicas de elaboração de projetos histórico-sociais baseado na realidade dos alunos. No entanto, fundamentalmente, a nova oferta editorial, ou atualiza a proposta para uma história temática apresentada há cerca de uma década e que ainda mostra fôlego comercial e acadêmico, ${ }^{42}$ ou abrange os pressupostos, as condições e as metas da aprendizagem 
regulamentadas por decretos - como o de $\mathrm{n}^{\circ}$. 10.639/03, que introduziu no currículo a obrigatoriedade da temática História e Cultura Afro-Brasileira, e o no ${ }^{\circ}$ 11.645/08, que a atualiza -, sugeridos pelos atuais índices de avaliação educacional. Trata-se de uma oferta que, tanto responde a uma demanda já reconhecida, quanto repete as fórmulas já experimentadas.

Sob esse ponto de vista, pode-se pensar com Michel de Certeau que, como os estudos históricos, também os manuais didáticos estão muito mais ligados "ao complexo de uma fabricação específica e coletiva do que ao estatuto de efeito de uma filosofia pessoal". "3 Não só uma interpretação, a elaboração de novas pertinências, um modo de organização característico enunciam uma operação que se situa num conjunto de práticas como, ainda, esboçam um lugar institucional e as leis de um meio. Conforme avaliam Choppin e Bittencourt, nem por isso a obra didática deixa de ser uma representação que a sociedade quer dar de si mesma. ${ }^{44}$ Como discurso para e sobre a docência, os manuais do professor trazem os efeitos disso na maneira que refletem a situação extraverbal da qual tratam. Da representação que esse tipo de texto, por exemplo, apresenta do ensino e da escola apreende-se melhor o discurso historiográfico acerca da didática da História do que sobre as condiçōes do ensino de História na escola. Principalmente as formas de avaliação instituídas pelo PNLD, asseguram uma seleção pelos pares que apreciam a obra didática segundo critérios científicos, decisivos para que o autor seja "acreditado". ${ }^{45}$ No caso dos manuais do professor, observa-se que se afigura um ensino pensado sobre o instrumental metódico e teórico da História, mas que ignora muito das dificuldades que os professores de História têm de passar para apreender um pouco das realidades que tentam explicar.

Assim, os textos de apoio, as referências bibliográficas, as sugestôes de registro e o conjunto de atividades que o Guia de Livros Didáticos PNLD-2008 - História ressalta e tanto valoriza nos manuais do professor, não devem se passar por meros subsídios para orientar metodologicamente o trabalho docente e assegurar boa formação ao professor. Nesse repertório de textos e elementos de referência, que o "Manual do Professor" compila, também é marcante o tipo de escolha, pois ela remete a uma certa percepção que se tem do destinatário. Em geral, observa-se o que o edital de convocação determina, como "recursos que contribuam para a formação do professor", uma seleção de textos de apoio e indicações bibliográficas voltados para a discussão historiográfica. ${ }^{46}$ A citação e compilação de textos de especialistas sobre determinada questão, ou período histórico, e mesmo as indicações de leitura desempenham um papel de atualização e de esclarecimento das propostas do livro didático. Entretanto, para autores como Munakata e Torres, a centralidade que o livro didático assume nesse âmbito de preocupaçóes repousa na suspeita de que os professores não teriam tido formação adequada. ${ }^{47}$ Há, por outro lado, recursos didáticos que os próprios manuais trazem elaborado para uso do professor. Nesse sentido, as fichas de avaliação, os organogramas da coleção e as sugestões de planejamento são insumos de trabalho que também reforçam a separação entre os que planejam o ensino e os que executam. Paim tem insistido na ideia que sob a prescrição desses modelos criam-se técnicas que o professor deve repassar. ${ }^{48}$ Outras indicações que visam orientar o trabalho escolar são as de sítios eletrônicos e de filmes. A incorporação de outras linguagens além da escrita no ensino de História tem feito do computador e do cinema recursos cada vez mais explorados nos manuais do professor. $\mathrm{Na}$ concepção de ensino de História e pesquisa escolar que se vai consolidando nas obras didáticas, as possibilidades de trabalho com os recursos da informática e com os produtos da indústria do entretenimento ganham uma grande importância didática. Sobretudo quando permitem explorar uma área fronteiriça entre a discussão historiográfica e as circunstâncias nas quais se desenvolve o trabalho docente. ${ }^{49}$

Essas inserções textuais no enunciado dos manuais são do mesmo tipo do que Choppin chamou de paratexto das obras didáticas para tratar de uma estrutura que não mais possibilita uma leitura continuada. ${ }^{50}$ As ilustraçóes, os textos citados, os exercícios e as questôes rompem o percurso linear do textobase tanto no livro do aluno quanto no manual que acompanha o exemplar do professor. O paratexto nos manuais do professor também produz uma concepção de docência. Principalmente, os textos com- 
plementares, os excertos, as indicações bibliográficas e de material e as sugestôes de atividades apontam que o domínio dos conteúdos por parte do professor é uma preocupação central. Os subsídios que se indica e se procura organizar por meio dos manuais do professor assumem o instrumental metodológico e teórico da História como condição de exercício da docência na área. Sem abrir mão das considerações sobre o que ensinar em História, o "Manual do Professor" se caracteriza hoje por ter de explicitar os pressupostos, as condições e metas da aprendizagem na disciplina específica da História e os meios do seu ensino. Quando se analisa a maneira como as conexões entre o texto-base e o paratexto é realizada, no exemplar do professor, pode-se perceber algo da terminologia que orienta as expectativas em relação ao exercício da docência em História. Ligar a vida presente ao legado da humanidade, compreender as realidades que se tenta explicar ou relacionar o fato aos temas e aos sujeitos que o produziram para buscar uma explicação, são ações consideradas parte do ofício da docência em História nesse tipo de impressos. Do mesmo modo que há expectativas quanto ao que é ensinado, espera-se que, na maneira de ensinar, o docente de História comente e explique a matéria, relacione os fatos, destaque conteúdos, demonstre os processos de mudança ao longo do tempo, informe sobre a atualidade de algumas questôes históricas e estimule a aprendizagem do aluno. Se em alguma medida pode-se concluir que a docência em História caracteriza-se por fazer intervir nos atuais assuntos de interesse da juventude as explicaçôes racionais e exigências de convivência e participação social, um dado interessante é a exígua presença de orientações relacionais que não as de ordem operacional: orientar, acompanhar, corrigir, estimular, avaliar, explicar, solicitar...

Isso se observa, sobretudo, na parte específica dos manuais do professor. A recorrência com que se convenciona a ação do professor em sala de aula, nas orientações específicas por série dos manuais, resulta numa concepção de docência pautada em categorias como habilidade, competência e autonomia. Relacionar, compreender, explicar, acompanhar, orientar, corrigir e avaliar são, tanto expressões da ordem das habilidades, quanto das competências que se solicitam dos docentes nos manuais didáticos. Não há coleção recomendada no PNLD-2008 desprovida desse tipo de percepção da docência. A preocupação com os expedientes de exposição dos conteúdos, de desenvolvimento das atividades e de devolução dos resultados produz uma seleção de meios linguísticos, não só do ponto de vista da sua adequação ao objeto do discurso, mas da perspectiva do proposto fundo aperceptivel do destinatário do discurso. ${ }^{51}$ Portanto, uma peculiaridade constitutiva e determinante da parte específica dos manuais do professor é a forma típica com que representa a docência em História. Pressupõe-se um trabalho autônomo, operado em função do conteúdo pedagógico das atividades propostas para compreensão e estudo da matéria e segundo um repertório de procedimentos metódicos de aula. O "Manual do Professor" justifica e fundamenta esse trabalho instrumental sobre os exercícios e o seu controle, dando preferência às práticas de produção textual e pesquisa dos alunos em detrimento da memorização e da cópia.

Sob esses termos, a didática que se constrói para o ensino de História nos manuais do professor parece definida por uma combinação de práticas articuladas e apresentadas sob a forma de atividades. Efetivamente, para Choppin, a dimensão dinâmica da obra didática atribui funções especiais aos exercícios, às questōes e às atividades que se estendem sobre a paginação e demais características tipográficas. ${ }^{52} \mathrm{~A}$ estrutura editorial que os manuais do professor organizam, em parte específica, para discutir as respostas dos exercícios propostos no livro do aluno e sugerir outras atividades e ações, também compreende quadros explicativos, pictogramas de sinalização e manchas visando permitir ao usuário apreender a forma como a obra foi instrumentalizada. Por um lado, conforme explica Choppin, nem tudo figura no mesmo plano, sendo modesto o lugar que ocupa a localização ou mera memorização de informações. Ao contrário, a análise e a dissertação, o debate, a interpretação e a crítica colocam em jogo, não só o rigor nas deduçōes, as posições pessoais e a criatividade dos alunos, mas as orientações e a mediação do próprio professor. Por outro lado, os procedimentos retóricos que assim organizam as propostas de exercícios evidenciam as posições do autor quanto às estratégias de produção do conhecimento histórico na 
sala de aula. Nem sempre a compreensão do leitor-docente é deixada por conta da estruturação a qual o "Manual do Professor" se presta. Geralmente por meio do recurso às introduções ou de inserções explicativas e incisos, os autores se pronunciam e esclarecem suas opções de procedimento. Nessas passagens do texto, a relação valorativa do autor com o objeto do seu discurso favorece o estudo das representações que se constrói sobre a docência. As pistas linguísticas responsáveis por introduzir no texto a posição do autor, não só contribuem para a percepção dos mecanismos persuasivos, então utilizados, como para analisar os tipos de estratégias através das quais o autor pode expressar seu pensamento.

\section{A indicação dos critérios para a seleção dos conteúdos pedagógicos e da disciplina}

$\mathrm{Na}$ indicação dos critérios para seleção dos conteúdos pedagógicos e da disciplina que os manuais do professor registram nas introduções, ou nas inserções explicativas e incisos, segue o investimento dos autores em enunciar e produzir uma interpretação correta. Como hoje advertem as pesquisas acerca do uso do livro didático, esse esforço chega a ser proporcional ao grau de liberdade do usuário perante a obra didática. Quanto mais se postula que os leitores reais não se conformam ao leitor suposto pelo discurso, melhor elaborados são os artifícios que visam a fazer com que o "Manual do Professor" seja lido por seu leitor como um discurso competente. ${ }^{53}$ Nas coleçôes didáticas em que os enunciados na primeira pessoa do plural predominam nos textos dos manuais do professor, as escolhas e rejeições dos autores, assim como algo de suas prioridades, são explicitadas. Na parte específica desses manuais, encontramos os incisos, nos quais são acentuadas, sobretudo, as orientações adicionais que os autores prestam a respeito da realização dos exercícios, indicando, por outro lado, a expertise desses autores. Esclarecimentos do tipo "usamos o termo 'região' e não cidade, município ou bairro, porque, em muitos casos, as atividades econômicas apresentam um caráter regional envolvendo vários municípios", ou "partimos dos diversos significados atuais do termo república, bem como da etimologia da palavra, vinculando-a à ideia de 'coisa pública', ou seja de garantia do interesse coletivo", sublinham o conhecimento que os autores têm acerca do que se propóem tratar.

Nesses casos, existe o envolvimento pessoal dos autores com o discurso e uma maior exposição diante do leitor. Conforme advertem, entre outros, Bakhtin e Booth, na verdade, não se tem acesso a esse sujeito senão por aquilo que ele enuncia, tratando-se, por isso, de um autor apenas constituído pelo texto; aquele que pertence ao campo da teoria da enunciação. ${ }^{54}$ Não obstante a efetividade do que assinala a teoria, tanto quanto o lugar de onde fala o autor e os seus valores pedagógicos e políticos e experiência profissional, a forma como o autor se coloca no texto determina a construção e o estilo do enunciado. Quando se consideram os discursos como atos - o sistema dos pronomes, os advérbios de circunstância, as conexões, os tempos e modos verbais - é possível reconhecer, na relação entre o texto e aquele que o produziu, as relações entre as posições actanciais do enunciador e a do enunciatário. ${ }^{55}$ Nos manuais do professor em que predominam os enunciados na primeira pessoa do plural essas relações são constituídas sob a forma de sugestão, amenizando-se o caráter mais ou menos imperativo das instruções. Assim, fórmulas como "sugerimos um momento de discussão sobre o mapa em sala de aula e até mesmo de decifração de algumas inscrições"; "sugerimos que essas questões sejam representadas para os alunos, levando-os a se indagarem sobre as respostas dadas no início dos trabalhos", ou "sugerimos que cada grupo de cinco alunos entreviste apenas cinco pessoas", atestam a autonomia do docenteleitor, procurando influir por meio de recomendações.

Uma variação dessa forma é o recurso ao plural majestático, ou a troca da primeira pessoa do plural pela primeira do singular, quando se trata de um enunciador que usa o "nós" porque se pretende um indivíduo que não fala em seu próprio nome, mas em nome de um "saber". Nesses casos, também é reconhecida a autonomia do leitor e do docente e há uma constante amenização das formas verbais imperativas, predominando as sugestôes. Com efeito, são recorrentes os enunciados do tipo "sugerimos ainda 
que se dê especial atenção ao boxe sobre Pompeia" e "apresentamos a seguir uma proposta que pode ser adaptada e reproduzida". Na primeira pessoa, os textos dos manuais do professor, tanto explicitam com maior precisão as escolhas, quanto expõem as posições do autor sob a forma de considerações. Evidência disso é o frequente recurso, nessas coleçôes, a expressões como "consideramos oportuno lembrar", "optamos partir das...", ou "tomamos o cuidado de escolher".

Por outro lado, há coleções didáticas em que se preferiu utilizar formas de indeterminação do sujeito nos enunciados dos manuais do professor. Segundo Fiorin, a forma indeterminada serve para que o enunciador se esvazie de toda e qualquer subjetividade e se apresente apenas como papel social. ${ }^{56}$ Nos manuais do professor em que esse tipo de enunciado predomina, geralmente, as indicações operacionais recrudescem sob a forma de propostas e pretensões. Afirmações acerca das expectativas de aprendizagem são as mais recorrentes nesse sentido: "pretende-se formar no aluno a habilidade de leituras diferenciadas, respeitando a natureza explicativa de cada uma delas sem a preocupação de confrontá- las e classificá-las como verdadeiras ou falsas"; "procura-se despertar nos alunos o interesse pelas civilizações grega e romana”. Nesses casos, as prescrições também se apoiam em evidências que, se julga, sejam compartilhadas por todos. Passagens como, por exemplo, "parte-se dos valores e eventos do passado que permanecem vivos no presente, para não só estabelecer o vínculo entre passado e presente, mas também atestar a força que as tradições exercem sobre o presente", ou "introduz-se, neste capítulo, o estudo do período de consolidação da democracia grega e da formação de seu patrimônio cultural, procurando demonstrar a necessidade de lutar para preservar as conquistas", presumem que o estudo da História deve influir nas atuais formas de convivência.

Entre as sugestôes dos textos em primeira pessoa e as propostas e pretensões dos textos que se utilizam das formas indeterminadas, em lugar da primeira pessoa, ocorrem maneiras intermediárias de enunciar os critérios para a seleção dos conteúdos pedagógicos e da disciplina nos manuais do professor. Há casos em que ocorre o uso da primeira pessoa do plural para expressar pretensóes quanto ao trabalho com os conceitos históricos e um acentuado emprego dos modos verbais imperativos. Já outras coleções publicadas, embora utilizem formas indeterminadas em lugar da primeira pessoa, manifestamse por meio de sugestôes e do emprego de uma série de recursos para amenizar o caráter mais ou menos imperativo que envolve as suas proposiçôes. As diferentes formas de o autor intervir no texto do "Manual do Professor" conformam certos contornos; desenham, a partir das seleçōes operadas e dos traços manifestados do seu agenciamento, o que Denis Bertrand chama de disposição cognitiva. ${ }^{57}$ Para Bertrand, "o sujeito pragmático da enunciação torna-se desde então 'configurável', como um feixe de atitudes em relação aos objetos de conhecimento que ele põe no lugar e que dispõe, segundo as aberturas e as coerçôes de uma certa ordem do saber" ${ }^{58}$ Nesse sentido, o autor que se constitui implicitamente no texto é responsável pela conclusividade específica do enunciado. ${ }^{59} \mathrm{O}$ conjunto de avaliaçóes e as representações que, desse modo, ele efetiva no discurso se afiguram de modo a fazer reconhecer uma maneira própria de estar no mundo.

Em relação ao que é enunciado no "Manual do Professor", as inserções explicativas e incisos nos quais o autor se instala em primeira pessoa, ou se indetermina no texto, não são mais do que uma pequena parte do seu discurso. As demais estratégias actanciais e recursos para o autor tornar inteligível seus propósitos se dão sob a forma do gênero, no qual o enunciado foi construído. Assim, a intenção discursiva do autor, sua vontade discursiva, também se revela nas estratégias linguísticas propiciadas pelo gênero do discurso escolhido. Os manuais do professor das coleções didáticas, recomendadas pelo PNLD-2008, são determinados por considerações técnicas e por princípios que se busca transformar em regras de ação práticas. Entre tantas outras, essa especificidade configura os procedimentos composicionais e meios linguísticos que, conforme fazem pensar as proposições de Bakhtin e de Bertrand, refletem a posição social e o peso do destinatário. Nessa perspectiva, um levantamento sumário dos indícios linguísticos que materializam o leitor implícito nos textos desses impressos adverte que o insistente 
uso das formas verbais imperativas ou, então, a escolha do modo indicativo quando se busca orientar uma ação prática do professor, não é uma mera opção estilística.

\section{A docência em História nos manuais do professor}

Retomando a maneira ativa como Bakhtin percebe o destinatário de um enunciado, compreendese que a escolha dos procedimentos composicionais e dos meios linguísticos do texto leva em conta a sua compreensão responsiva, projetando na obra uma representação do leitor. Segundo Fiorin, "o texto constrói um tipo de leitor chamado a participar de seus valores" e que, assim, "intervém indiretamente como filtro e produtor do texto". ${ }^{60}$ Quando, nos manuais do professor, o autor busca orientar uma ação prática é ao seu leitor presumido - o professor - a quem se dirige. A atenção para o estudo dos dispositivos e dos mecanismos, graças aos quais os textos materializam o leitor que esse autor tem em mente, é particularmente fecunda para se compreender a forma como ele expressa uma representação sobre a docência. É dessa perspectiva que o gênero didático e o estilo do discurso dos manuais do professor servem de signos visíveis de uma determinada compreensão do exercício do magistério.

O uso recorrente do imperativo é o primeiro elemento capaz de revelar o funcionamento refletido da representação nos manuais do professor. Operar o sentido do fazer no texto, através de ordens que pretendem organizar a ação, descrevê-la, ou prescrevê-la, tem sido a prática no "Manual do Professor". Esses textos constroem o leitor-docente dizendo-lhe o que fazer, como se suspeitassem da sua escassa formação e experiência e do que lhe falta saber. Por um lado, trata-se de um modo usual de dar eficácia ao que foi pensado como necessário para a transmissão de conhecimentos. Entretanto, é igualmente um meio de fixar uma fórmula de trabalho. Expressões como "faça uma revisão com a turma sobre a contagem do tempo", ou "chame a atenção dos alunos para a existência de engenhos onde se fabrica açúcar" e "destaque a relação entre portugueses e índios", visam persuadir o docente a incorporar essas açōes na sua prática através de determinaçôes. Nas coleçôes em que as orientaçôes se dão preferencialmente assim, o papel do docente, para quem construiu o texto, fica reduzido a de um executor de tarefas.

Também há outros modos de dizer o que é pressuposto e condição da ação docente nos manuais de ensino de História. Em muitas coleções recomendadas no PNLD-2008, os esclarecimentos sobre os conteúdos da disciplina visam contribuir para se ver com maior clareza o que deve ser ensinado. As longas sequências sobre a Lei de Terras de 1850 ou acerca da democracia grega no "Manual do Professor" favorecem a concretização de uma possibilidade de abordagem da matéria em detrimento de outras. Conforme advertem Ciampi e outros autores, muitas vezes, na prática, o docente se relaciona com a historiografia como se ela portasse a verdade sobre o tema, e não como uma representação dela ${ }^{61}$ Nesse sentido, os manuais do professor elaboram séries inteiras de discursos segundos, ou derivados, por cujo intermédio é outorgada competência aos interlocutores que puderem assimilá-los. Podem-se distinguir duas formas principais de fazê-lo. Primeiramente, as explicações do conteúdo são apresentadas para informar o leitor, ou como respostas às questões propostas no livro do aluno. Em ambos os casos, dãose soluçôes de inteligibilidade aos critérios de expressão e às problemáticas discutidas no livro do aluno como, por exemplo, na passagem que se segue:

Após a abdicação de D. Pedro I, vários conflitos ameaçaram fragmentar o território brasileiro em diversas naçôes independentes. Por quase vinte anos o governo regencial e o imperial lutaram contra a ameaça separatista, procurando fortalecer o poder central.

Resultado, o Brasil entrou a década de 1850 como uma nação consolidada, tendo reconhecido o poder do imperador e até mesmo reunindo relativas condições para o desenvolvimento econômico.

Entretanto, o país ainda se caracterizava pela ordem oligárquica, fundamentada na economia de latifúndios movidos pela mão-de-obra escrava. A Lei de Terras de 1850 é o melhor exemplo da permanência do poder oligárquico, uma vez que restringiu o acesso da população pobre à propriedade da terra. ${ }^{62}$ 
A segunda forma geral de trazer orientação, visando o êxito do docente na consecução do ensino, tem sido tratar das questóes de método. O "Manual do Professor" das coleções didáticas de História propõe estratégias de ensino e metodologias de abordagem que, introduzindo e apresentando o conteúdo, ou como destaques de seção, possibilitam criar determinadas situações de aprendizagem. Isso se observa bem na passagem abaixo:

O que é importante, neste capítulo, além da análise dos movimentos dos anos 20, é mostrar ao aluno as várias interpretaçôes a respeito da Revolução de 1930. Existe uma extensa literatura sobre esse tema, apresentando inúmeras possibilidades de análise do movimento e a participação de atores políticos diferentes, o que permite ao professor, trabalhar com o aluno a constatação de que não há uma verdade absoluta na história e que as várias versões são discursos historiográficos escritos de acordo com valores de sua época. Estes, por sua vez, são construídos sobre outros discursos da época, que são as fontes utilizadas pelo historiador. É uma chance para que o aluno compreenda que não pode recuperar o passado, mas, sim, estudar os discursos, nas suas diversas linguagens, feitos no e sobre o passado. ${ }^{63}$

Expedientes desse tipo são característicos dos manuais do professor que acompanham os livros didáticos de História recomendados pelo PNLD-2008. A se acreditar, como Chauí e Paim, que por detrás do discurso competente do especialista já está pressuposta a incompetência do não-especialista, a mediação do "Manual do Professor" apenas permite a ilusão de o professor participar do saber histórico especializado. Nesse sentido, os estudos acerca dos discursos que se criam para e sobre os professores advertem a respeito das mudanças dos significados originais de várias categorias e expressóes historicamente relacionadas ao exercício qualificado da docência. Suspeita-se de um mascaramento das reais intenções das propostas que hoje se pautam em categorias como habilidade, competência, autonomia da escola e do professor. Conforme avalia Mônica Silva, do modo como esses termos estão incorporados aos dispositivos normativos evidenciam apenas uma linguagem de natureza prescritiva e funcional. ${ }^{64}$

Os boxes, os incisos e inserções explicativas, os destaques e os textos complementares são outro conjunto de dispositivos discursivos e editoriais que nos manuais do professor constituem o aparelho formal da enunciação nas coleçôes didáticas de História. Tanto quanto o recurso às formas verbais, esses auxílios resultam de escolhas que revelam algo das perspectivas que se tem sobre a docência. $\mathrm{O}$ empenho voltado para fornecer recursos diversificados ao professor se traduz nos pontos da matéria e estratégias que são tratados à parte, em boxes, ou destacados em seções específicas, nas considerações a respeito do conteúdo e da prática e no que se complementa por meio de textos citados. Esse expediente atende ao que é solicitado em edital e parece assentado numa percepção de que os professores não tiveram formação adequada. Entradas como, por exemplo, "Atenção, professor"; "Orientações adicionais para o professor"; "Comentário" e "Dica”, introduzem uma proposta de estratégia, ou insistem na importância de algum conteúdo específico. Da mesma forma, destaques do tipo "ler com expressão para motivar o interesse pelo tema”, ou boxes visando ampliar o que há para dizer de um determinado conteúdo e propondo atividades indicam que se escreve para o leitor de um guia de trabalho. Assim, também os textos complementares e demais indicações de bibliografia, sítios eletrônicos, filmes e instituições de pesquisa, buscam contribuir com referências acerca do que falta ao professor ter ou saber. Nesta perspectiva, o "Manual do Professor", sobretudo, constitui repertórios inteiros de atividades, imagens e referências de material impresso e audiovisual.

Além das orientações de método e de conteúdo e do repertório indicado de materiais, as referências acerca da docência, apresentadas nos manuais do professor, fazem reconhecer uma certa maneira de exercer o magistério. As solicitações de atividades, os destaques, os incisos e inserções explicativas, contidas nesse tipo de impresso, envolvem uma determinada concepção do seu destinatário. Os manuais das 19 coleçôes didáticas de História recomendadas pelo PNLD-2008 demandam ações do professor por meio do uso, entre muitos outros, de verbos como orientar, esclarecer, escolher, selecionar, propor, coordenar, estabelecer critérios, explicar, auxiliar e apresentar conclusões. Conforme apontei 
anteriormente, trabalha-se, assim, numa lógica que pressupõe o domínio de uma série de habilidades e competências por parte do professor e não reconhece nos saberes e estratégias próprias do seu ofício um móvel da prática, um meio de "criar condições para o trabalho coletivo numa situação de pressão institucional". ${ }^{65} \mathrm{O}$ estudo das solicitações de atividade e leitura indicadas nos manuais do professor foi aqui uma maneira de inventariar os modos pelos quais a prática do ensino de História é percebida.

A maneira como esses manuais caracterizam a ação, ou o conhecimento que se solicita do professor, articula atividades pragmáticas e cognitivas. Recorrentes, os períodos do tipo "você pode orientar o trabalho de pesquisa nos grupos e a organização dos dados obtidos", ou "ensine aos alunos como fazer o fichamento dos livros que leem", lembram ao seu leitor que há esquemas de ações breves, estáveis e simples de fazer para ensinar procedimentos de estudo. Por outro lado, indicaçôes como "consulte e leia esse material, de forma a garantir uma formação continuada" e "cabe ao professor avaliar a coerência e a argumentação dos alunos" insistem que as condiçōes do fazer dependem de um saber. Saber e fazer e saberfazer são condiçōes da prática docente que não se encontram facilmente nos manuais do professor das coleções didáticas de História. Em muitos aspectos, o investimento que é realizado no "Manual do Professor", para engendrar dinâmicas de evolução do ofício, mascara toda uma série de ações profissionais ordinárias, mas sem estatuto no discurso de formação docente. Assim, apesar das insistentes recomendações acerca do trabalho com diferentes linguagens, com fontes e recursos audiovisuais, por meio de dramatizações e de jogos e de organização de eventos, debates e passeios, não há o que se encontrar nesses impressos sobre os constrangimentos específicos do exercício da docência. As formas de organização da classe e o controle da sua disciplina, os gestos, as maneiras de fazer e os procedimentos de conduta, entre outras tantas ações implícitas da aula, são largamente ignoradas diante da preocupação com as questôes metodológicas da matéria, os processos de aprendizagem, e as modalidades de atividade e avaliação.

O trabalho com os manuais permite constituir não mais que um repertório das invariantes estruturais do ensino de História. Desse modo, as estratégias constitutivas da prática do ensino de História, consideradas dignas de serem transmitidas, se passam por evidências do saber docente valorizado nessa disciplina. As rotinas de elaboração visual das aprendizagens (cartazes, painéis e construção de materiais), de discussão e reflexão (debates, seminários e entrevistas), de síntese (exposições, resumos) e as dinâmicas de jogos e representações prescritas nos manuais do professor das coleções didáticas, então recomendadas no PNLD-2008, fazem reconhecer uma prática que privilegia a cultura da participação. Igualmente, abordagens didáticas, cada vez mais capazes de refletir os avanços da ciência histórica e a incorporação de soluções pedagógicas propostas para o ensino de História, visam atingir o fundo e a forma da narração histórica em sala de aula. Nesse sentido, as múltiplas práticas de ensino que assim se pode identificar não deixam de se fundar e de dar expressão a um conjunto de padrões didáticos estruturados e sugeridos no país para o ensino da História no processo da chamada abertura democrática de fins dos anos 70 do século passado. Contudo, hoje, a incorporação pelas instituições daquele discurso de redefinição da História ensinada possui significados próprios e segue numa perspectiva de reforçar a separação entre os que pensam e os que fazem. ${ }^{66}$ Não por acaso, como as reformas educacionais das últimas duas décadas, os manuais do professor dão crédito aos procedimentos de trabalho racionalmente realizáveis, passíveis de planejamento e registro e a docência é representada, simplesmente, como capaz de reiterá-los.

\section{As fórmulas estereotipadas da interação didática no ensino de História}

As pesquisas sobre as maneiras de o professor realizar seu trabalho em sala de aula e de usar os materiais didáticos mostram que, no fazer cotidiano, os docentes tornam possíveis variações em relação ao prescrito e planejado. Os estudos de Araújo, Cassiano, Soares, Bittencourt e Rocha vêm documentando expedientes de ensino e administração do dia-a-dia da sala de aula que impedem perceber o professor como simples executor de modelos prescritos. ${ }^{67}$ Não obstante uma literatura que trata dos níveis de autonomia e de planejamento do professor, aquela perspectiva persiste nos manuais do professor das co- 
leçōes didáticas de História como característica de seu gênero discursivo. ${ }^{68}$ Conforme insiste Bakhtin, todos os enunciados "possuem formas relativamente estáveis e típicas de construção do todo". ${ }^{69}$ Desse modo, persuadir o leitor a respeito da melhor forma de uso da obra parece ser, em muitos dos seus sentidos, uma exigência do manual. Contudo, os espaços de ação que o docente se autoriza ter e que as pesquisas recentes fazem reconhecer não são ignoradas. Os manuais do professor preveem a possibilidade de escolha e decisão do professor numa pequena parte das suas instruções, assumindo que há limites à apropriação das orientações prescritas.

As formulações do tipo "o professor deve escolher", ou "você deverá escolher", dão solução à necessidade de estimular o professor a compreender que seu local de atuação deve ser utilizado como fonte de recursos e materiais didáticos. $\mathrm{O}$ apelo mais direto nessa direção diz respeito ao reconhecimento de que a cultura material disponível no ambiente, nos museus ou arquivos de uma determinada cidade, é parte dos recursos para lecionar História. Assim, não há, nos manuais do professor das coleções assim orientadas, relutância ou subterfúgio algum em delegar aos docentes escolhas quanto aos objetos de trabalho, mais de acordo com a realidade local. Nesse mesmo sentido, as escolhas quanto à organização das atividades recomendadas no "Manual do Professor" indicam, igualmente, que há uma autonomia necessária ao exercício da docência. Noutro extremo dessa situação, a validade que as escolhas do professor têm para o ensino apenas se manifesta de modo hipotético. A variação sobre o prescrito é apenas considerada abstratamente, sem que se acentue sua necessidade, ou a possibilidade de que venha a se realizar. O reiterado emprego de expressões como "você pode (ou poderia) orientar, estabelecer"; "seria interessante que você"; "se o professor achar conveniente", ou "pode-se ainda propor" denotam uma situação, cuja condição de realização é desconhecida do emissor. Essa relação do enunciado linguístico com a realidade é ilustrativa do lugar que as escolhas do professor têm nos discursos endereçados para quem atua na prática. Mesmo nas coleções em que se reconhece certa liberdade que o professor tem para escolher objetos de ensino e pesquisa e procedimentos didáticos, essa tem sido a forma predominante de expressar a autonomia docente. Complementar às demandas da necessidade e às condições de realização do ensino, outra maneira de se reconhecer o espaço de manobra do professor na sala de aula relaciona-se com as possíveis adaptaçōes que então se podem fazer e com as alternativas, cuja conveniência, a própria prescrição considera. De antemão, o texto dos manuais do professor indica o que vem a ser passível de ser adaptado e reproduzido e pondera sobre o que é indiferente aplicar, como atividade individual, em dupla, ou grupo, ou, ainda, conduzir oralmente ou por escrito.

Essas fórmulas vêm se fixando nos manuais do professor, refletindo as discussões a respeito das possibilidades de autonomia no exercício do magistério. Outros tipos recorrentes de formulaçõos servem às necessidades de escrever sobre o trabalho ordinário dos docentes aos docentes. A colaboração entre professores de disciplinas diferentes, a sistematização dos conhecimentos prévios dos alunos, as atitudes que se pretende que o aluno desenvolva, constituem um repertório de fórmulas correntes nos atuais manuais do professor. Trata-se de recursos reiterados nas orientaçōes ao docente que acompanham as coleções didáticas de História. Bakhtin fala em estereótipos no discurso, quando se identifica procedimentos comuns de enunciação, relativamente regularizados no canal de interação social que lhes é reservado, reforçados pelo uso e pelas circunstâncias. ${ }^{70}$ Nesse sentido, as formas particulares de palavras-alusões fazem reconhecer elementos da interação que o ensino de História delimita, por exemplo, com o currículo, a sociedade e o aluno (interesse).

No que se refere ao currículo, a requisição da participação de professores de outras disciplinas nas propostas de atividades de História é normalmente o meio pelo qual se proclamam os ideais da interdisciplinaridade, ou a transversalidade curricular, nos manuais do professor das coleçōes didáticas da área. Assim, as indicações acerca das possibilidades de colaboração dos professores de Matemática e Ciências, ou a solicitação da participação de docentes das áreas de Geografia, Artes, Língua Portuguesa e Educação Física, preveem a importância e a necessidade de atividades multidisciplinares. Ocorre que a iniciativa se limita a essa espécie de personalização do componente curricular no docente. Mesmo promo- 
vendo ações conjuntas entre professores, na maior parte das vezes, os manuais didáticos das coleções escolares de História desconsideram que a interdisciplinaridade envolve raciocínio específico e um planejamento de aula conjugado entre diferentes disciplinas. Ainda são poucas as orientações que percebem o próprio conhecimento histórico como interdisciplinar. Em todo caso, as formulaçôes sobre a interdisciplinaridade se dão em qualquer manual do professor, refletindo certa representação acerca do ensino da matéria e das suas relações com o currículo escolar.

A respeito das finalidades sociais do ensino de História, a contribuição que ele oferece para a construção de uma cidadania enraizada numa comunidade é reiteradamente proclamada. Conforme mostrou Circe Bittencourt, "o papel da História como disciplina encarregada da formação do cidadão político não é velado ou implícito, como ocorre nas demais disciplinas curriculares". ${ }^{71}$ Propõe-se formar cidadãos para uma vida solidária e democrática, com visão crítica da realidade e espírito participativo. Há expectativas nesse sentido, quanto ao desenvolvimento de atitudes e procedimentos e à possibilidade de elaborar conhecimentos a partir da experiência. Os manuais do professor das coleções didáticas de História recomendadas pelo PNLD-2008 registram que o ensino da matéria contribui para construir uma comunidade aberta a outras solidariedades que não a da nação e, assim, uma perspectiva indispensável para o exercício do pensamento livre. Todas essas fórmulas servem às necessidades de elaboração do papel do ensino da História no currículo, sendo, portanto, elementos regulares do discurso sobre o ensino de História que se veiculam nos manuais da disciplina. Elas são delimitadas e determinadas, sobretudo, pela missão que se confia ao ensino de História, aos seus professores e à escola.

Outra formulação que participa das diferentes formas de construção dos enunciados sobre o ensino de História nos manuais didáticos é a do interesse dos alunos. As orientações ao professor desses manuais solicitam que os docentes despertem e explorem o envolvimento do aluno com as problemáticas propostas no ensino da História. Mobilizar os alunos para refletir sobre o conhecimento histórico é, invariavelmente, apontado como responsabilidade do professor. Nos manuais didáticos, as condiçóes para criar o interesse da classe pela abordagem da matéria estão associadas ao "talento" do professor para instigar e envolver todos os participantes, estimulando-os. Nesse sentido, há coleções que subsidiam essa prática com sugestôes de questões motivadoras, filmes, músicas e brincadeiras. Outras coleçōes demandam do professor estimular os alunos a interrogar, refletir, levantar dúvidas e observar, motivá-los nas tarefas e produções. Ainda que, mesmo assim, não se deixe de acreditar que a execução das atividades propostas, por si só, produza aprendizagem, os manuais do professor das coleções didáticas de História solicitam a presença do docente nas dinâmicas de aprendizagem.

As ideias de Bakhtin sobre a estrutura sociológica da enunciação mostram que "toda situação inscrita duravelmente nos costumes possui um auditório organizado de uma certa maneira e, consequentemente, um certo repertório de pequenas fórmulas correntes"..$^{72}$ Depois de duas décadas de funcionamento do PNLD, as coleções didáticas são parte da rotina escolar e têm se adaptado a esse meio social, refletindo a forma de suas estruturas de funcionamento, seus objetivos e a composição social do grupo que as formula. Também nos manuais do professor encontram-se formas específicas de construção das enunciações que, além de um uso característico de palavras-alusões, expressam obrigação, fins e uma qualificação do ofício. Mais uma vez, a relevância dessas configurações discursivas específicas, para o estudo dos métodos e técnicas de ensino, diz respeito às operações de recorte e de classificação, graças às quais produzem certa percepção da realidade.

A construção de enunciações que Bakhtin considera haver nos lugares de trabalho, na escola, parece ser representativa das relações que a docência mantém com as práticas do seu ofício, com o conhecimento e com o aluno. Há vestígios das relaçóes que se travam na escola, nos textos dos manuais do professor. Nota-se primeiro que a relação de poder expressa pelas obrigações do ofício docente fica sempre muito reduzida aos serviços ordinários. O planejamento, o registro, a orientação das atividades, a correção dos resultados, o estímulo à atenção do aluno, a distribuição dos materiais e a organização do trabalho e da apresentação dos alunos em sala, são os imperativos cotidianos reiterados ao docente-leitor, a cada novo 
conjunto de temas e atividades. Por outro lado, as finalidades do ensino se estendem desmesuradamente. Além de contribuir para a formação de cidadãos e construir uma ideia clara dos acontecimentos e processos históricos e de sua sucessão no tempo, pede-se ao professor de História que também provoque atitudes solidárias de convívio social e tolerância, promova o desenvolvimento do juízo crítico e desenvolva a competência leitora dos seus alunos. Entre outros tantos exemplos, desenvolver habilidades cognitivas, como capacidade de análise, inferência, interpretação e síntese e valorizar o patrimônio histórico e cultural de diferentes sociedades, tem se associado nos manuais do professor às tarefas impostas pela inclusão de diferentes visões do passado no ensino da História do país e da crítica ao eurocentrismo.

Entre o que se concede e aquilo que se demanda do professor, constata-se que os manuais das coleçôes didáticas de História formalizam as configurações por meio das quais a docência e a aprendizagem devem ser percebidas. Assim, ainda que percebida, em função das suas atividades mais ordinárias, a docência de História tem sido apresentada nos manuais do professor sob a perspectiva da eficácia. É o professor de História que ajuda a ordenar um discurso sobre o mundo, cria possibilidades de investigação dos processos históricos locais e dá tratamento didático capaz de facilitar ao aluno o exercício do pensamento livre. O ofício, então, requer preparo para problematizar, para analisar e questionar a realidade de uma atualidade, sem tradição ou passado. Em muitos sentidos, o professor de História, que os manuais das coleções didáticas revelam, não é o mesmo que definem como seu destinatário.

\section{Notas}

${ }^{1}$ A pesquisa da qual resultou este artigo contou com financiamento do CNPq.

${ }^{2}$ PROST, Antoine. As palavras. In: RÉMOND, Réne (Org.) Por uma história politica. Rio de Janeiro: FGV Editora, 1996, p. 137.

${ }^{3}$ BENVENISTE, Emile. Problèmes de linguistique générale. Paris: Gallimard, 1966 (vol. 1) e 1974 (vol. 2). SEARLE, John. R. Os actos de fala: um ensaio de filosofia da linguagem. Coimbra: Livraria Almedina, 1981 e Expressão e significado: estudos da teoria dos atos de fala. São Paulo: Martins Fontes, 1995. FOUCAULT, Michel. A arqueologia do saber. 7.ed. Rio de Janeiro: Forense Universitária, 2008. p. 98.

${ }^{4}$ JAKOBSON, Roman. Linguistica e comunicação. São Paulo: Cultrix; Edusp, 1969; GREIMAS, A. J. Semântica estrutural. São Paulo: Cultrix; Edusp, 1973; KERBRAT-ORECCHIONI, Catherine. L'énonciation. De la subjectivité dasn le langage. Paris: Armand Colin, 1980 e FIORIN, José Luís. As astúcias da enunciação: as categorias de pessoa, espaço e tempo. 2a ed. São Paulo: Ática, 2008.

${ }^{5}$ KERBRAT-ORECCHIONI, Catherine. Op. cit., p. 29-30.

${ }^{6}$ BAKHTIN, Mikhail. Marxismo e filosofia da linguagem: problemas fundamentais do método sociológico na ciência da linguagem. G.ed. São Paulo, 1992. p. 123.

${ }^{7}$ Cf. TODOROV, Tzvetan. Mikhail Bakhtin: le principe dialogique. Paris: Seuil, 1981.

${ }^{8}$ BURKE, Peter. Bakhtin for historians. Social History, 13, p. 85-90, 1998; e O que é história cultural? Rio de Janeiro: Zahar, 2005.

${ }^{9}$ TODOROV, Tzvetan. Problèmes de l'énonciation. Langages. Paris, no ${ }^{\circ}$ 17, p. 3-11, mar. 1970; FIORIN, José Luiz. As astúcias da enunciação. Op. cit.

${ }^{10}$ STAM, R. Bakhtin: da teoria literária à cultura de massa. São Paulo: Ática, 2000.

${ }^{11}$ PONZIO, A. A revolução bakbtiniana. São Paulo: Contexto, 2008.

${ }^{12}$ BAKHTIN, Mikhail. Marxismo e filosofia da linguagem. Op. cit., p. 124-125.

${ }^{13}$ CHOPPIN, Alain. Pasado y presente de los manuales escolares. In: BERRIO, J. L. (Org.) La cultura escolar de Europa: tendencias históricas emergentes. Madrid: Editorial Biblioteca Nueva, 2000, p. 107-141 e CHARTIER, Anne-Marie. Práticas de leitura e escrita: história e atualidade. Belo Horizonte: Autêntica, 2007.

${ }^{14}$ BAKHTIN, Mikhail. Estética da criação verbal. São Paulo: Martins Fontes, 2006. p. 289; 301.

${ }^{15}$ BAKHTIN, Mikhail. Estética da criação verbal. Op. cit., p. 289.

${ }^{16}$ CHERVEL, A. História das disciplinas escolares: reflexōes sobre um campo de pesquisa. Teoria \& Educaşão. no ${ }^{\circ} .2,1990$, p. 204; e FORQUIN, Jean-Claude. Saberes escolares, imperativos didáticos e dinâmicas sociais. Teoria \& Educação. nº. 5 , 1992, p. 35. 
${ }^{17}$ BAKHTIN, Mikhail. Estética da criação verbal. Op. cit., p. 294.

${ }^{18}$ BAKHTIN, Mikhail. Estética da criação verbal. Op. cit., p. 289-293.

${ }^{19}$ FORQUIN, Jean-Claude. Op. cit., p. 34.

${ }^{20}$ BAKHTIN, Mikhail. Estética da criação verbal. Op. cit., p. 296-297.

${ }^{21}$ Idem., p. 297.

${ }^{22}$ Idem.

${ }^{23}$ Idem, p. 299.

${ }^{24}$ Idem, p. 301.

${ }^{25}$ Idem.

${ }^{26}$ Idem, p. 302.

${ }^{27}$ Cf. BITTENCOURT, Circe. Livro didático e conhecimento histórico: uma história do saber escolar. São Paulo, 1993. Tese (Doutorado) - Faculdade de Filosofia, Letras e Ciências Humanas da Universidade de São Paulo; GASPARELLO, Arlette Medeiros. Construtores de identidades: a pedagogia da nação nos livros didáticos da escola secundária brasileira. São Paulo: Iglu Editora, 2004; e FREITAS, Itamar. Histórias do ensino de história no Brasil. São Cristovão: Ed. UFS; Aracaju: Fundação Oviêdo Teixeira, 2006.

${ }^{28}$ BITTENCOURT, Circe. Ensino de História: fundamentos e métodos. São Paulo: Cortez, 2004 (Coleção Docência em Formação: série Ensino Fundamental).

${ }^{29}$ Cf. FREITAS, Itamar. Op. cit.

${ }^{30}$ Cf. CERTEAU, M. de. A invenção do cotidiano. vol. 01 - Artes de fazer. São Paulo: Vozes, 1994; JAUSS, H. R. Pour une esthétique de la réception. Paris: Gallimard, 1978; e BURKE, P. História e teoria social. São Paulo: Ed. UNESP, 2002.

${ }^{31}$ ARAÚJO, Luciana Telles. O uso do livro didático no ensino de história: depoimentos de professores de escolas estaduais de ensino fundamental situadas em São Paulo. São Paulo, 2001. Dissertação (Mestrado) - Programa de Estudos Pós-Graduados em Educação: História, Política, Sociedade da PUC-SP; OLIVEIRA, Margarida Maria Dias. Livros didáticos de História: pesquisa, ensino e novas utilizações deste objeto cultural. In. OLIVEIRA, Margarida Maria Dias \& OLIVEIRA, Almir Félix Batista (Orgs.). Livros didáticos de História: escolhas e utilizaçōes. Natal: EDUFRN, 2009, p. 79-86; e ROCHA, Helenice Aparecida Bastos. Livros didáticos de história: diversidade de leitores e de usos. In: ROCHA, H. A. B.; REZNIK, L; MAGALHÂES, M. S. (Orgs.). A história na escola: autores, livros e leituras. Rio de Janeiro: FGV Editora, 2009. p. 201-226.

32 BITTENCOURT, Circe. Ensino de História: fundamentos e métodos. Op. cit., p. 317.

${ }^{33}$ ARAÚJO, Luciana Telles. O uso do livro didático no ensino de história. Op. cit., 2001, apud BITTENCOURT, Circe. Ensino de História: fundamentos e métodos. Op. cit., p. 318.

${ }^{34}$ BAKHTIN, Mikhail. Estética da criação verbal. Op. cit., p. 272.

${ }^{35}$ Idem, p. 275.

${ }^{36}$ Idem, p. 302.

${ }^{37}$ Cf. FIORIN, José Luís. As astúcias da enunciação. Op. cit.

${ }^{38}$ Cf. BAKHTIN, Mikhail. Estética da criação verbal. São Paulo: Martins Fontes, 2006. p. 304.

${ }^{39}$ Cf. NUNES, Clarice. Escola nova no Brasil: do estado da arte à arte do estudo. In: GVIRTZ, Silvina (Org.) Escuela nueva em Argentina y Brasil. Buenos Aires: Miño y Dávila, 1995, p. 14-15; PROST, Antoine. As palavras. Op. cit., p. 319; e CERTEAU, Michel de. A invenção do cotidiano. Op. cit., p. 72-73.

${ }^{40}$ Em primeira edição as coleçōes Projeto Araribá, História em Projetos, História, Sociedade \& Cidadania, Encontros com a História, Diálogos com a História, Construindo Consciências-História, Por dentro da História e História Hoje, são exemplos de projetos editoriais bem sucedidos no processo de avaliação do Programa Nacional do Livro Didático de 2008.

${ }^{41}$ PAULA, Andréa; FERRARESI, Carla; OLIVEIRA, Conceição. História em projetos. 4vol. Manual do Professor. São Paulo: Ática, 2007.

${ }^{42}$ Sobretudo é o caso da Coleção História Temática, de Montellato, Cabrini e Catelli. Noutra perspectiva de trabalho e organização dos conteúdos de História, as coleções Saber e Fazer História e História e Vida Integrada também são exemplos de sucesso editorial.

${ }^{43}$ CERTEAU, Michel de. Op. cit., p. 73.

${ }^{44}$ CHOPPIN, Alain. O Historiador e o livro escolar. História da Educação. Pelotas, v. 6, no 11 abr. 2002. p. 22 e BITTENCOURT, Circe. Ensino de História. Op. cit., p. 302.

${ }^{45}$ Cf. CERTEAU, Michel de. Op. cit., p. 72.

${ }^{46}$ BRASIL (MEC-FNDE). Edital de convocação para inscrição no processo de avaliação e seleção de obras didáticas a serem incluídas no Guia de Livros Didáticos para os anos finais do ensino fundamental. Disponível em <ftp://ftp.fnde.gov.br/ web/editaislicitações/edital_pnld-2008pdf> Acesso: 9 jan. 2007. p. 47. 
${ }^{47}$ MUNAKATA, Kazumi. O livro didático e o professor: entre a ortodoxia e a apropriação. In: MONTEIRO, A. M.; GASPARELLO, A. M.; MAGALHĀES, M. S. (Orgs.). Ensino de história: sujeitos, saberes e práticas. Rio de janeiro: Mauad X, 2007. p. 139; e TORRES, Rosa Maria. Melhorar a qualidade da educação básica? As estratégias do Banco Mundial. In: TOMMASI, L.; WARDE, M. J.; HADDAD, S. (Orgs.). O Banco Mundial e as políticas educacionais. 2.ed. São Paulo: Cortez, 1998. p. 160-161.

${ }^{48}$ PAIM, Elison. A. Do formar ao fazer-se professor. In: MONTEIRO, A. M.; GASPARELLO, A. M.; MAGALHÃES, M. S. (Org.). Ensino de história: sujeitos, saberes e práticas. Rio de Janeiro: Mauad X, 2007. p. 162.

${ }^{49}$ Os manuais de uso dos livros didáticos informam os sítios eletrônicos dos principais museus do país e de algumas das instituições de pesquisa histórica e de preservação do patrimônio histórico. Também são referenciados um extenso conjunto de filmes históricos nesse tipo de impresso.

${ }^{50} \mathrm{CHOPPIN}$, Alain. O Historiador e o livro escolar. Op. cit., p. 23.

${ }^{51}$ Cf. BAKHTIN, Mikhail. Estética da criação verbal. Op. cit., p. 304.

${ }^{52}$ CHOPPIN, Alain. O Historiador e o livro escolar. Op. cit., p. 23.

${ }^{53}$ Cf. CHAUÍ, Marilena. Cultura e democracia. 9.ed. São Paulo: Cortez, 2001.

${ }^{54}$ BAKHTIN, Mikhail. Questôes de literatura e estética. São Paulo: Hucitec: Unesp, 1988; BOOTH, Wayne. C. Distance et point de vue. Poétique. Paris: Seuil, 4, p. 511-524, 1970 e FIORIN. José Luís. Op. cit., p. 63.

${ }^{55}$ Cf. GREIMAS, A. J.; COURTÈS, J. Sémiotique: dictionnaire raisonné de la théorie du langage. vol. 1, Paris: Hachette, 1979. p. 125.

${ }^{56}$ FIORIN. José Luís. Op. cit., p. 86.

${ }^{57}$ BERTRAND, Denis. Du figuratif à l'abstrait. Actes sémiotiques. EHESS, CNRS, IV, 1982. p. 34-35.

${ }^{58}$ Apud FIORIN, José Luís. Op. cit., p. 63.

${ }^{59}$ Para Bakhtin, a inteireza acabada do enunciado, que assegura a possibilidade de compreensão responsiva, é determinada por três elementos intimamente ligados no enunciado: 1) exauribilidade do objeto e do sentido; 2) projeto de discurso ou vontade de discurso do falante; 3) formas típicas composicionais e de gênero do acabamento.

${ }^{60}$ FIORIN, José Luís. Op. cit., p. 64.

${ }^{61}$ CABRINI, Conceição et. ali. O ensino de história: revisão urgente. 2.ed. São Paulo: Brasiliense, 1986. Ciampi et. ali. (1990, p. 150-151),

${ }^{62}$ MODERNA. Projeto Araribá: História. 4vol. Manual do Professor, São Paulo: Moderna, 2006, v. 3, p. 79.

${ }^{63}$ RIBEIRO, Vanise; ANASTASIA, Carla, Encontros com a História. 4 vol. Curitiba: Positivo, 2006. v. 4, p. 21.

${ }^{64}$ SILVA, Mônica. Currículo e competências: a formação administrada. São Paulo: Cortez, 2008. p. 40.

${ }^{65}$ CHARTIER, Anne-Marie. Op. cit., p. 168.

${ }^{66}$ Cf. PAIM, Elison. Op. cit., p. 161 e CHAUÍ, Marilena. Op. cit., p. 13.

${ }^{67}$ BITTENCOURT, C. Livro didático e saber escolar: 1810-1910. Belo Horizonte: Autêntica, 2008; CASSIANO, Celia Cristina de Figueiredo. Circulação do livro didático: entre práticas e prescriçôes - políticas públicas, editoras, escolas e o professor na seleção do livro escolar. São Paulo, 2003. Dissertação (Mestrado) - Programa de Estudos Pós-Graduados em Educação: História, Política, Sociedade da PUC-SP; SOARES, Olavo Pereira. A atividade de ensino de história: processo de formação de professores e alunos. Araraquara: Junqueira \& Marin, 2008; ARAÚJO, Luciana Telles. Op. cit.; ROCHA, Helenice Ap. Op. cit.

${ }^{68}$ ARROYO, Miguel. Ofício de mestre: imagens e auto-imagens. São Paulo: Vozes, 2000; THERRIEN, Jacques; DAMASCENO, Maria Nobre (Orgs.). Artesãos de outro ofício: múltiplos saberes e práticas no cotidiano escolar. São Paulo: Annablume, 2000; PIMENTA, Selma Garrido. Professor reflexivo: construindo uma crítica. In: PIMENTA, Selma Garrido \& GHEDIN, Evandro. (Orgs.) Professor reflexivo no Brasil: gênese e síntese de um conceito. São Paulo: Cortez, 2002 e CONTRERAS, José. A autonomia dos professores. São Paulo: Cortez, 2002.

${ }^{69}$ BAKHTIN, Mikhail. Estética da criação verbal. Op. cit., p. 282.

${ }^{70}$ BAKHTIN, Mikhail. Marxismo e filosofia da linguagem. Op. cit., p. 126.

${ }^{71}$ BITTENCOURT, Circe. Livros didáticos entre textos e imagens. In: Paulo: Contexto, 1997. (Coleção Repensando e Ensino). p. 20. (Org.). O saber histórico na sala de aula. São

${ }^{72}$ BAKHTIN, Mikhail. Marxismo e filosofia da linguagem. Op. cit., p. 126. 


\section{Referências bibliográficas}

ARAÚJO, Luciana Telles. O uso do livro didático no ensino de história: depoimentos de professores de escolas estaduais de ensino fundamental situadas em São Paulo. São Paulo, 2001. Dissertação (Mestrado) - Programa de Estudos Pós-Graduados em Educação: História, Política, Sociedade da PUC-SP.

ARROYO, Miguel. Ofício de mestre: imagens e auto-imagens. São Paulo: Vozes, 2000.

BAKHTIN, Mikhail. Estética da criação verbal. São Paulo: Martins Fontes, 2006.

Questôes de literatura e estética (a teoria do romance). São Paulo: Hucitec; Ed. UNESP, 1988.

Marxismo e filosofia da linguagem: problemas fundamentais do método sociológico na ciência da linguagem. 6.ed. São Paulo, 1992.

BENVENISTE, Emile. Problèmes de linguistique générale. Vol. 2. Paris: Gallimard, 1974.

Problèmes de linguistique générale. Vol. 1. Paris: Gallimard, 1966.

BERTRAND, Denis. Du figuratif à l'abstrait. Actes sémiotiques. EHESS, CNRS, IV, 1982. p. 34-39.

BITTENCOURT, Circe Maria. Livro didático e saber escolar: 1810-1910. Belo Horizonte: Autêntica, 2008.

Livros didáticos entre textos e imagens. In: (Org.). O saber histórico na sala de aula. São Paulo:

Contexto, 1997. (Coleção Repensando e Ensino)

Ensino de História: fundamentos e métodos. São Paulo: Cortez, 2004. (Coleção Docência em Formação: série Ensino Fundamental)

Livro didático e conhecimento histórico: uma história do saber escolar. São Paulo, 1993. Tese (Doutorado) - Faculdade de Filosofia, Letras e Ciências Humanas da Universidade de São Paulo.

BOOTH, Wayne C. Distance et point de vue. Poétique. Paris: Seuil, 4, 1970. p. 511-524.

BRASIL (MEC-FNDE). Edital de convocação para inscrição no processo de avaliação e seleção de obras didáticas a serem incluídas no Guia de Livros Didáticos para os anos finais do ensino fundamental. Disponível em $<\mathrm{ftp}$ //ftp.fnde.gov.br/web/editaislicitações/edital_pnld-2008pdf> 63 fls. Acesso: 9 jan. 2007.

BURKE, Peter. Bakhtin for historians. Social History, 13, 1998. p. 85-90.

História e teoria social. São Paulo: Ed. UNESP, 2002.

O que é história cultural? Rio de Janeiro: Zahar, 2005.

CABRINI, Conceição et alii. O ensino de história: revisão urgente. 2.ed. São Paulo: Brasiliense, 1986.

CASSIANO, Celia Cristina de Figueiredo. Circulação do livro didático: entre práticas e prescrições - políticas públicas, editoras, escolas e o professor na seleção do livro escolar. São Paulo, 2003. Dissertação (Mestrado) - Programa de Estudos Pós-Graduados em Educação: História, Política, Sociedade da PUC-SP.

CHARTIER, Anne-Marie. Práticas de leitura e escrita: história e atualidade. Belo Horizonte: Autêntica, 2007.

CHAUÍ, Marilena. Cultura e democracia. 9.ed. São Paulo: Cortez, 2001.

CHERVEL, André. História das disciplinas escolares: reflexões sobre um campo de pesquisa. Teoria \& Educação. no. 2, 1990. p. 177-229.

CHOPPIN, Alain. O Historiador e o livro escolar. História da Educação. Pelotas, v. 6, no. 11, abr. 2002. p. 5-24.

CERTEAU, Michel de. A invenção do cotidiano. vol. 1 - Artes de fazer. São Paulo: Vozes, 1994.

CONTRERAS, José. A autonomia dos professores. São Paulo: Cortez, 2002.

FIORIN, José Luís. As astúcias da enunciação: as categorias de pessoa, espaço e tempo. 2.ed. São Paulo: Ática, 2008. FORQUIN, Jean-Claude. Saberes escolares, imperativos didáticos e dinâmicas sociais. Teoria \& Educação. no. 05, 1992. p. 28-49.

FOUCAULT, Michel. A arqueologia do saber. 7.ed. Rio de Janeiro: Forense Universitária, 2008.

FREITAS, Itamar. Histórias do ensino de história no Brasil. São Cristovão: Ed. UFS; Aracaju: Fundação Oviêdo Teixeira, 2006.

GASPARELLO, Arlette Medeiros. Construtores de identidades: a pedagogia da nação nos livros didáticos da escola secundária brasileira. São Paulo: Iglu Editora, 2004. 
GREIMAS, Algirdas Julien. Semântica estrutural. São Paulo: Cultrix; Edusp, 1973.

GREIMAS, Algirdas Julien \& COURTÈS, Joseph. Sémiotique: dictionnaire raisonné de la théorie du langage. vol. 1, Paris: Hachette, 1979.

JAKOBSON, Roman. Linguistica e comunicação. São Paulo: Cultrix; Edusp, 1969.

JAUSS, H. R. Pour une esthétique de la réception. Paris: Gallimard, 1978.

ROCHA, Helenice Aparecida Bastos. Livros didáticos de história: diversidade de leitores e de usos. In: ROCHA, H. A. B.; REZNIK, L; MAGALHĀES, M. S. (Orgs.). A história na escola: autores, livros e leituras. Rio de Janeiro: FGV editora, 2009. p. 201-226.

SEARLE, John. Os actos de fala: um ensaio de filosofia da linguagem. Coimbra: Livraria Almedina, 1981.

SEARLE, John. Expressão e significado: estudos da teoria dos atos de fala. São Paulo: Martins Fontes, 1995.

SILVA, Mônica. Curriculo e competências: a formação administrada. São Paulo: Cortez, 2008.

SOARES, Olavo Pereira. A atividade de ensino de história: processo de formação de professores e alunos. Araraquara: Junqueira \& Marin, 2008.

STAM, R. Bakhtin: da teoria literária à cultura de massa. São Paulo: Ática, 2000.

THERRIEN, Jacques \& DAMASCENO, Maria Nobre (Orgs.). Artesãos de outro ofício: múltiplos saberes e práticas no cotidiano escolar. São Paulo: Annablume, 2000.

TODOROV, Tzvetan. Mikhail Bakhtin: le principe dialogique. Paris: Seuil, 1981.

TORRES, Rosa Maria. Melhorar a qualidade da educação básica? As estratégias do Banco Mundial. In: TOMMASI, Livia; WARDE, Miriam Jorge; HADDAD, Sérgio (Orgs.). O Banco Mundial e as politicas educacionais. 2.ed. São Paulo: Cortez, 1998.

\section{RESUMO}

Este artigo consiste em um estudo sobre os modos de enunciação dos Manuais de Ensino para professores de História. Tomando como fontes de pesquisa os livros recomendados pelo Programa Nacional do Livro Didático de 2008 (PNLD2008), o texto examina a configuração discursiva desse recurso didático. Os modos de enunciação nos Manuais do Professor são analisados considerando o gênero dos textos, a intenção discursiva dos autores e o modelo de docente; eles também são analisados como práticas de representação do ensino e da aprendizagem.

Palavras-chave: ensino de História; manuais do professor; prática docente.

\section{ABSTRACT}

This article consists of a study on the enunciation modes found in Teaching Handbooks for History teachers. Using as basis for the research the textbooks recommended by the 2008 National Textbook Program (PNLD-2008), the text examines the discursive configuration of that didactic resource. The enunciation modes in the Teaching Handbooks for History teachers are analyzed taking in consideration the genus of the text, the discursive intention of the authors and the teacher models; they are also analyzed as practices of representation of teaching and learning.

Keywords: teaching of History; teaching handbooks; teacher practice. 